Al-Bidayah : jurnal pendidikan dasar Islam

Volume 12, Number 2, December 2020

ISSN: 2549-3388 (online)

Available online at https://jurnal.albidayah.id

Submitted: March 14, 2020, Accepted: December 21, 2020

\title{
THE DEVELOPMENT OF FRACTION TEXTBOOK WITH THE ETHNOMATHEMATICS APPROACH FOR THIRD GRADE STUDENT OF MADRASAH IBTIDAIYAH
}

\author{
Linda Indiyarti Putri ${ }^{1}$, Nurwidiyanto ${ }^{2}$, Alfiana Rohmah ${ }^{3}$ \\ Universitas Wahid Hasyim, Indonesia ${ }^{1,3}$, Northeast Normal University, China ${ }^{2}$ \\ E-mail: lindaputri5@gmail.com¹,zi1997@nenu.edu.cn²,rohmahalfiana@gmail.com³
}

DOI: 10.14421/al-bidayah.v12i2.535

\begin{abstract}
The development of a fraction textbook with an Ethnomathematics approach for the third-grade student of Madrasah Ibtidaiyah (MI) has an urgency to be implemented in fulfilling the alternative needs for learning mathematics textually and realistically. This study aims to determine the effectiveness of fraction material textbooks with an ethnomathematics approach in Madrasah Ibtidaiyah. The population of the study was the third-grade students of MI Roudlotul Huda of Sekaran Gunungpati. The development model is carried out using the concept of development research according to Borg and Gall's 4D model. The sample of this study is using simple random sampling. Product trials were carried out in two class groups, namely IIIA as the experimental class and III B as the control class. The method of obtaining data used questionnaires, tests, and documentation. Then, the early step analysis of the data used the homogeneity and normality test. Furthermore, the data were analyzed using independent samples t-test and paired samples t-test. The product validation analysis results based on the material aspects state that the fraction textbooks with an ethnomathematics approach are suitable to use with a percentage of $75.8 \%$ and $75.8 \%$ from the material aspect. Meanwhile, response to textbook products in the attractive category obtained a percentage of $89 \%$.
\end{abstract}

Keywords: textbook; ethnomathematics; simplifying fraction

\section{INTRODUCTION}

Learning is a form of interaction between teachers and teaching participants. If communication is well established, the learning process will take place optimally. According to Daryanto in Nurmutiatun, the teaching and learning process is essentially a communication process, delivering messages from the introduction and the recipient. ${ }^{1}$ It follows Law No. 20 of 2003 concerning the National Education System Article 1 Paragraph 20 states that learning is a process of interaction between students and educators and learning resources in an environment. From this opinion, learning is a process of interaction between teachers and students in a particular environment sourced from learning resources relevant to the materials.

1 Nurmayuni Astuti, “Analisis Pengetahuan Prosedural Siswa SMA Kelas X Berdasarkan Tipe Kepribadian Dalam Menyelesaikan Soal Matematika," Ekuivalen - Pendidikan Matematika 31, no. 1 (February 5, 2018): 19-24, https://doi.org/10.37729/ekuivalen.v31i1.4355.

reative Commons Non Commercial CC BY-NC: This article is distributed under the terms of the Creative Commons Attribution Non Commercial 4.0 License (http://www.creativecommons.org/licenses/by-nc/4.0/) which permits noncommercial use, reproduction and distribution of the work without further permission provided the original work is attributed as specified on the Al-Bidayah : jurnal pendidikan dasar Islam and Open Access pages 
Learning resources are all sources to be utilized by a person to facilitate all learning activities to achieve the desired learning objectives. ${ }^{2}$ Therefore, suitable and relevant learning resource selection will help teachers to deliver materials optimally. Meeting the need for learning resources must be adjusted to students' level of cognitive abilities, including mathematics. ${ }^{3}$ Mathematics has an abstract object of study, bases itself on universal conventions, uses a deductive mindset, and is imbued with consistent truths. ${ }^{4}$ Mathematical concepts can be easily understood if following students' cognitive development stage at the basic level, i.e., concrete operations. ${ }^{5}$

One of the weaknesses in learning mathematics is that the teacher's quality of learning is still low. It is evident from the information provided by class IIIA and IIIB teachers when teaching mathematics. They are still accustomed to teaching habits by using learning steps such as: presenting learning material textually and presented using conventional and expository teaching methods. The teachers provide examples of questions and ask students to do the practice questions in the textbooks they use to teach and then discuss them together.

Furthermore, observation results demonstrated that the learning process was not student-oriented. The opportunities for third-grade students of MI Roudhotul Huda to actively participate in the learning process were not optimal since the teacher is the primary source. Students were struggling to link the materials and real-life situations. When students faced a problem, most students found challenges in expressing or presenting the problem, situation, and ideas into a mathematics model or figure.

When mathematics learning occurs, students felt insecure and hesitant in asking or answering questions from the teacher. Students only accepted what is being conveyed by the teacher so that the ability to construct understanding independently has not happened to students. Ironically, the assumption of mathematics being not essential and

\footnotetext{
${ }^{2}$ Sita Ratnaningsih and Genasty Nastiti, "Upaya Meningkatan Motivasi Belajar Siswa Dengan Menggunakan Media Gambar Pada Pembelajaran Tematik Di Sekolah Dasar," Al Ibtida: Jurnal Pendidikan Guru MI 5, no. 2 (2018): 275, https://doi.org/10.24235/al.ibtida.snj.v5i2.3397.

3 Tati Nurhayati, Dwi Anita Alfiani, and Dewi Setiani, "The Effect of Crossword Puzzle Application on The Students' Learning Motivation in Science Learning," Al Ibtida: Jurnal Pendidikan Guru MI 6, no. 1 (2019): 124, https://doi.org/10.24235/al.ibtida.snj.v6i1.4186.

${ }^{4}$ Nur Malasari and Arif Rahman Hakim, "Pengembangan Media Belajar Pada Operasi Hitung Untuk Tingkat Sekolah Dasar," JKPM (Jurnal Kajian Pendidikan Matematika) 3, no. 1 (2017): 11, https://doi.org/10.30998/jkpm.v3i1.1911.

5 Linda Indiyarti Putri and Abdul Basir, "Papan Jam Analog: Media Edukatif Pembelajaran Matematika Madrasah Ibtidaiyah,” Edumatika: Jurnal Riset Pendidikan Matematika 3, no. 1 (2020): 33, https://doi.org/10.32939/ejrpm.v3i1.501.
} 
has no use in everyday life was delivered by several third-grade students of MI Roudhotul Huda. In this problem, the role of apperception at the beginning of learning helps students understand. ${ }^{6}$ Mathematics is built from daily life experiences so that it will bring students closer to concrete contextual mathematics. ${ }^{7}$ The more directly the object studied, the more concrete the knowledge obtained. ${ }^{8}$

Contextual and realistic mathematics is a form of integration between mathematics and culture, where a group of people has carried out mathematical practices without realizing it, which is presented in ethnomathematics studies. ${ }^{9}$ Ethnomathematical findings by several researchers contributed to presenting contextual and realistic mathematics learning material in schools. Cultural values can be conveyed in ethnomathematics-based learning so that it is expected to contribute to building a nationalist character in students. According to Fatimah, ethnomathematics as a mathematics education that integrates cultural values in mathematics learning needs to integrate these cultural values. The integration starts from the curriculum to the planning and implementation of learning. ${ }^{10}$

Alfonsa stated in his article that if learning is adjusted to students' lives, it will certainly not be too difficult to adjust, especially in mathematics learning which has a high level of abstractness. Abstract concepts that only exist in the shadow of students can be transformed into their lives. ${ }^{11}$ The reinvention nature of mathematics makes it rediscovered by understanding or following how the knowledge is found, including, in this case, students can naturally find and conclude the mathematics learning process

\footnotetext{
6 Distia Putri, "Pengaruh Apersepsi Dan Motivasi Terhadap Hasil Belajar IPS Kelas V SD Negeri 16 Kota Bengkulu" (Diploma Thesis, Bengkulu, IAIN Bengkulu, 2019), http://repository.iainbengkulu.ac.id/3736/.

7 Jonni Sitorus and Masrayati, "Students' Creative Thinking Process Stages: Implementation of Realistic Mathematics Education," Thinking Skills and Creativity 22 (December 1, 2016): 111-20, https://doi.org/10.1016/j.tsc.2016.09.007.

${ }^{8}$ Fou-Lai Lin, Ting-Ying Wang, and Kai-Lin Yang, "Description and Evaluation of a Large-Scale Project to Facilitate Student Engagement in Learning Mathematics," Studies in Educational Evaluation 58 (September 1, 2018): 178-86, https://doi.org/10.1016/j.stueduc.2018.03.001.

${ }^{9}$ Sri Supiyati, Farida Hanum, and Jailani, "Ethnomathematics in Sasaknese Architecture," Journal on Mathematics Education 10, no. 1 (2019): 47-57, https://doi.org/10.22342/jme.10.1.5383.47-58.

10 Sitti Fatimah S. Sirate, "Menggagas Integrasi Multikultur Pembelajaran Matematika: Suatu Telaah Etnomatematika," Auladuna: Jurnal Pendidikan Dasar Islam 2, no. 2 (December 31, 2015): 24663. http://journal.uin-alauddin.ac.id/index.php/auladuna/article/view/880.

11 Alfonsa M Abi, "Integrasi Etnomatematika Dalam Kurikulum Matematika Sekolah," JPMI (Jurnal Pendidikan Matematika Indonesia) 1, no. 1 (2017): 1, https://doi.org/10.26737/jpmi.v1i1.75.
} 
they experience both in formal education and beyond. ${ }^{12}$ Ethnomathematics is a strategy to bridge mathematics as a science and preserve a community that unconsciously implements the mathematics concept (culture) to provide students with meaning. ${ }^{13}$

A predecessor study proved that the ethnomathematics approach brought the learning process into a fun and meaningful process. One of which was through the engklek game with puzzle media. It developed the creativity and cognitive ability of students. There are elements of character education in togetherness, honesty, sportiveness, and others in the game process. ${ }^{14}$ In line with this, the description of ethnomathematics exploration in the design of traditional Lengkong houses provides the context for calculating geometric concepts, i.e., flat shapes (triangle, square, rectangle, trapezoid, and rhombus), flat side shapes (beam), lines (horizontal, vertical, and perpendicular), angles (acute angles), and geometric transformations (dilation and reflection). ${ }^{15}$

The results of this ethnomathematics study in the Naga village community provided information to the public that mathematics has a relationship with culture and is a recommendation for the mathematics curriculum in Indonesia. The mathematical concepts discovered were the units of length, area, and volume used by the Kampung Naga community and converted into standard units. Some of these previous findings show that mathematics is very close to everyday life, so that mathematics must be contextually conveyed to make learning meaningful.

12 Sri Rahmawati Fitriatien, "Pembelajaran Berbasis Etnomatematika" (Seminar Nasional Pendidikan Matematika Ikatan Alumni S3 Pendidikan Matematika, Surabaya: Pascasarjana Universitas Negeri Surabaya, 2016), https://www.researchgate.net/profile/SriFitriatien/publication/317318097_Pembelajaran_Berbasis_Etnomatematika/links/5931a4b2a6fdcc89e7a3 7493/Pembelajaran-Berbasis-Etnomatematika.pde.

13 Igor Verner, Khayriah Massarwe, and Daoud Bshouty, "Development of Competencies for Teaching Geometry through an Ethnomathematical Approach," The Journal of Mathematical Behavior 56 (December 1, 2019): 100708, https://doi.org/10.1016/j.jmathb.2019.05.002.

14 Cornelia Suryaningsih and Detalia Noriza Munahefi, "Penerapan Puzzle Bernuansa Etnomatematika Melalui Permainan Engklek Pada Materi Bangun Datar," PRISMA, Prosiding Seminar $\begin{array}{llllll}\text { Nasional Matematika } & 4 & \text { (February } & \text { 24, } & \text { 2021): } & 111-18 .\end{array}$ https://journal.unnes.ac.id/sju/index.php/prisma/article/view/45008.

${ }^{15}$ Nining Yuningsih, Indah Nursuprianah, and Budi Manfaat, "Eksplorasi Etnomatematika Pada Rancang Bangun Rumah Adat Lengkong," Jurnal Riset Pendidikan Matematika Jakarta 3, no. 1 (February 24, 2021): 1-13, https://doi.org/10.21009/jrpmj.v3i1.19517. 
Learning models with ethnomathematics content are implemented to improve student learning outcomes. ${ }^{16}$ It has been proven from the results of hypothesis testing, which shows that there are differences in the average motivation and learning outcomes of students with ethnomathematics content with students who follow conventional learning models. The simultaneous average of mathematics learning motivation and learning outcomes of the experimental group was higher than the average mathematics learning motivation and learning outcomes of the control group. ${ }^{17}$

The implementation of the fractional mathematics concept practice, i.e., the focus of the development of ethnomathematics-based teaching material conducted by the communities for centuries, is the culture of distributing plunder to those who are entitled to it:

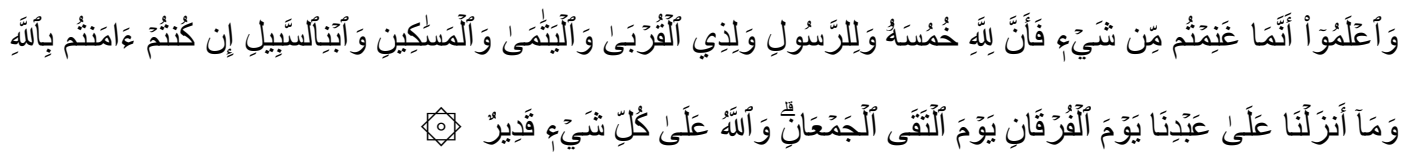

"Know that one-fifth of the spoils that you obtain belongs to Allah, to the Messenger, to the near of kin, to the orphans, and the needy, and the wayfarer. This you must observe if you truly believe In Allah and in what We sent down on Our servant on the day when the true was distinguished from the false, the day on which the two armies met in battle. Allah has power over all things" (QS. Al Anfaal, verse 41). ${ }^{18}$

Observing the urgent need for the ethnomathematics-based fraction learning material in third-grade of MI Roudhotul Huda, this study aimed to create a learning material of fraction teaching book with the ethnomathematics approach as a contribution to realistic and contextual mathematics learning.

\section{RESEARCH METHODS}

This study's population was all the third-grade students of MI Roudhlotul Huda Semarang in the academic year 2019/2020. The sampling of the study is using a simple random sampling technique. The trial was carried out in two class groups, namely IIIA

\footnotetext{
${ }^{16}$ Igor Verner, Khayriah Massarwe, and Daoud Bshouty, "Constructs of Engagement Emerging in an Ethnomathematically-Based Teacher Education Course," The Journal of Mathematical Behavior 32, no. 3 (September 1, 2013): 494-507, https://doi.org/10.1016/j.jmathb.2013.06.002.

${ }^{17}$ I Wayan Eka Mahendra, "Project Based Learning Bermuatan Etnomatematika Dalam Pembelajar Matematika," JPI (Jurnal Pendidikan Indonesia) 6, no. 1 (2017): 106-14, https://doi.org/10.23887/jpiundiksha.v6i1.9257.

${ }^{18}$ Minister of Religious Affairs, Al-Quran Tajwid Dan Terjemahnya Dilengkapi Dengan Asbabun Nuzul Dan Hadits Shahih (Bandung: Syaamil Quran, 2010), 186.
} 
as the experimental class and IIIB as the control class. The data were analyzed using the preliminary data test. They were the homogeneity test and the normality test, then the data were analyzed using the independent samples t-test and paired samples t-test after it was stated homogeneous and normal.

Both sample classes in this study had the same simple fraction material. Preliminary data were obtained from the Daily Test scores in odd semesters to determine that the research sample was obtained from population conditions normally distributed and homogeneous. The experimental class was given fraction mathematics learning treatment using textbooks with an ethnomathematics approach, and the control class obtained expository learning.

The data collection technique was carried out using documentation, test, and questionnaire techniques. The documentation method is used to obtain data on the students' early abilities as the samples of the study. The test method was used to obtain the data on simple fractions' cognitive abilities using multiple-choice tests that had previously been tested. Meanwhile, the questionnaire method was used to obtain the data about the differences in the students' attitudes towards a culture of pre and postapplication of mathematics learning with the ethnomathematics approach.

This study is Research and Development (R\&D) study, and this development research uses the 4D method, which has four steps: Define, Design, Development, and Dissemination. Define has two activities: first, identify the problem, the researcher makes an observation at Roudhlotul Huda Islamic Elementary School (MI) of Sekaran Gunungpati and doesn't found any textbook with an ethnomathematics approach as an effort to improve the students' understanding of fraction material in third-grade. Second, analyzing the setting was carried out by collecting data on the characteristics of the research subject. They are the third-grade students of MI Roudhlotul Huda of Sekaran Gunungpati. In addition, the researcher has also conducted an interview with the thirdgrade teachers. They are Ms. Puji and the previous second teacher, Ms. Indi. Both teachers said that the numeracy scores of third-grade students were still lacking and had not yet reached the minimum completeness criteria. ${ }^{19}$

The design has some activities: First, the emergence of potentials and problems, there is no textbooks with an ethnic-mathematic approach as an effort to improve the

19 Endang Mulyatiningsih and Apri Nuryanto, Metode Penelitian Terapan Bidang Pendidikan (Bandung: Alfabeta, 2014), 195. 
students' understanding of fraction material in third grade. Second, this product's goal is the availability of a tool product to measure the capability in solving integrated fractional problems with daily problems, then introducing the traditional cultural forms that exist in society early. Third, idea development is carried out based on input from the supervisor. Fourth, filtering ideas, the researcher filters the input from the supervisor. Fifth, evaluation, the researcher demand input from the supervisor. Sixth, consumer considerations, the researcher asks some opinions from the math teacher of MI Roudhlotul Huda of Sekaran Gunungpati. Seventh, rude product design or commencement. $^{20}$

Develop has two activities: First, an expert appraisal is a technique for validating or assessing the appropriateness of product designs that were carried out by experts in their fields. The expert teams who validate teaching material products are media and material experts. Apart from being validated by experts, this research was also reviewed by the third-grade homeroom teacher. Second, developmental testing, it is an activity to test product design on the real target subject. The first step of testing product to the students is to share pictures, displays, ethnomathematics based learning media with the theme of fractions to the control class, which contains 23 students and the experimental class contains 21 students, last, distribute questionnaire sheets of the students' responses to an ethnic-mathematic approach teaching material with the theme of fractions. ${ }^{21}$

Dissemination was conducted by publishing this research results in the central library repository of Universitas Wahid Hasyim Semarang. Thus, this study gives useful values both in the empirical context in the field and as material for academic studies for subsequent research.

\section{RESULT AND DISCUSSION}

The learning material's development model utilized was research and development $(\mathrm{R} \& \mathrm{D})$. This study was conducted until the product revision stage due to the time limitation to perform distribution. This research and development aimed to develop a product in the form of a learning module with Simple Fraction as the primary material for class III. It was adjusted to the Elementary School student's development level.

\footnotetext{
${ }^{20}$ Sugiyono, Metode Penelitian Dan Pengembangan (Bandung: Alfabeta, 2017), 446.

${ }^{21}$ Mulyatiningsih and Nuryanto, Metode Penelitian Terapan Bidang Pendidikan, 198.
} 
The first step was determining the problems and potentials. Problem and potential identification were carried out in this step. Based on the questionnaire results distributed to teachers, it was discovered that teachers only used subject textbooks, students' worksheets, and nature since they are abundant and readily available in the school.

On the information collection step at MI Roudhlotul Huda Sekaran, data was obtained in class III's curriculum, syllabus, and mathematics textbook. Besides, the teacher only used the books provided at the school to teach students. For this reason, the information collection step results were used as a guideline for the development of teaching materials in the form of textbooks. The textbook developed contains the Simple Fraction subject with an ethnomathematics approach to class III of elementary school.

The product design step concerned the appearance and flow of the teaching material program in ethnomathematics learning model design, cover design, animation design, and material design to make the textbook attractive and focused. The textbook was then tested for media and material validation by expert teams. After two revisions, the expert media team stated that the fraction textbook with an ethnomathematics approach was feasible, with a percentage of $77.8 \%$. Meanwhile, material experts stated that the fraction textbook with an ethnomathematics approach was feasible, with a percentage of $75.8 \%$.

The data collection technique was utilized to determine the response to using the fraction mathematics textbook with an ethnomathematics approach by a questionnaire. Class III students' response was a total score of 1960 with an average score of 44.5 and a percentage of $89 \%$. The response result from students to the ethnomathematics-based learning material with the fraction theme to improve learning achievements of MI Roudhlotul Huda Sekaran Gunungpati students was interesting to use.

After acknowledging student responses, the researcher then carried out the initial stage analysis, i.e., normality and homogeneity tests of data. The normality test is a prerequisite test for the paired t-test. The normality test aims to determine whether the data used in the study comes from a normally distributed population or not. In this test, the initial hypothesis $\left(H_{0}\right)$ states that the data comes from a normally distributed population, and the alternative hypothesis $\left(H_{l}\right)$ states that the data does not come from a 
normally distributed population. With $\alpha=5 \%$ (.05) drawing conclusions based on $H_{0}$ is accepted if $p>\alpha$.

Table 1

\begin{tabular}{|c|c|c|c|c|c|}
\hline \multicolumn{6}{|c|}{ One-Sample Kolmogorov-Smirnov Test } \\
\hline & & $\begin{array}{c}\text { Control Class } \\
\text { Pre-Test } \\
\text { Score } \\
\end{array}$ & $\begin{array}{c}\text { Control Class } \\
\text { Post-Test } \\
\text { Score } \\
\end{array}$ & $\begin{array}{c}\text { Experiment } \\
\text { Class Pre-Test } \\
\text { Score } \\
\end{array}$ & $\begin{array}{l}\text { Experiment } \\
\text { Class Post- } \\
\text { Test Score }\end{array}$ \\
\hline$N$ & & 24 & 24 & 22 & 22 \\
\hline \multirow{2}{*}{ Normal Parameters } & $M$ & 65.00 & 69.67 & 61.73 & 79.55 \\
\hline & $S D$ & 9.753 & 13.704 & 8.559 & 13.175 \\
\hline \multirow{3}{*}{$\begin{array}{l}\text { Most Extreme } \\
\text { Differences }\end{array}$} & Absolute & .179 & .176 & .171 & .241 \\
\hline & Positive & .167 & .176 & .171 & .123 \\
\hline & Negative & -.179 & -.150 & -.102 & -.241 \\
\hline$Z$ & & .877 & .864 & .801 & 1.131 \\
\hline$p$ & & .425 & .444 & .542 & .155 \\
\hline
\end{tabular}

a. Test distribution is Normal.

b. Calculated from data.

Based on the One-Sample Kolmogorov - Smirnov table, $p$ value was .425 for the control class pre-test data, .444 for the control class post-test data, .542 for the experimental class pretest data, and .155 for the experimental class post-test data. It shows that $p>\alpha$ or $.425>.05 ; .444>.05 ; .542>.05 ; .155>.05$. Since $\mathrm{p}>\alpha$ it can be concluded that $H_{0}$ is accepted, meaning that data were sourced from a normally distributed population. Hence, the paired t-test is eligible.

After the normality test was carried out, the researcher conducted a prerequisite test for testing the independent sample t-test, i.e., the homogeneity test. This test is carried out to determine whether the two samples' variants are the same/homogeneous. It also affects making conclusions in the independent t-test conducted. The homogeneity test carried out using the Levene test.

Table 2

The Homogeneity Test Using The Levene Test

\begin{tabular}{llcc}
\hline & & \multicolumn{2}{c}{ Levene's Test for Equality of Variances } \\
\cline { 3 - 4 } & & $\mathrm{F}$ & $p$ \\
\hline Pre-Test Score & Equal variances assumed & .197 & .659 \\
\hline Post-Test Score & Equal variances assumed & 1.269 & .266 \\
\hline
\end{tabular}


From the homogeneity test table, it was discovered that the Levene statistical value for the learning achievement pretest score of class III students was 0.197 with $p$ .659. It concludes that the learning achievement pretest score of class III students was homogeneous. Therefore, during the independent t-test, a conclusion was drawn following the equal variances assumed table. The Levene statistical value for the learning achievement post-test score of class III was 1.269 with p .266. Since $p$, it was over .05 , it can be concluded that the learning achievement post-test score data of class III students was homogeneous. Therefore, during the independent t-test, a conclusion was drawn following the equal variances assumed table.

In order to find out whether there is a significant difference in the learning achievement results of class III students of MI Roudlotul Huda Sekaran Gunungpati both before and after the application of teaching materials with an ethnomathematics approach with the theme of fractions in both the control class and the experimental class, a paired t-test was carried out.

Table 3

Paired Samples Test

\begin{tabular}{|c|c|c|c|c|c|c|c|c|}
\hline & & \multicolumn{4}{|c|}{ Paired Differences } & \multirow[t]{3}{*}{$t$} & \multirow[t]{3}{*}{$d f$} & \multirow[t]{3}{*}{$p$} \\
\hline & & \multirow[t]{2}{*}{$M$} & \multirow[t]{2}{*}{$S D$} & \multicolumn{2}{|c|}{$\begin{array}{l}95 \% \text { Confidence } \\
\text { Interval of the } \\
\text { Difference } \\
\end{array}$} & & & \\
\hline & & & & Lower & Upper & & & \\
\hline $\begin{array}{c}\text { Pair } \\
1\end{array}$ & $\begin{array}{l}\text { Control Class Pre-Test } \\
\text { Score-Control Class Post- } \\
\text { Test Score }\end{array}$ & -4.667 & 12.662 & -10.013 & .680 & -1.806 & 23 & .084 \\
\hline $\begin{array}{c}\text { Pair } \\
2\end{array}$ & $\begin{array}{l}\text { Experiment Class Pre-Test } \\
\text { Score-Experiment Class } \\
\text { Post Test Score }\end{array}$ & -17.818 & 13.290 & -23.711 & -11.926 & -6.288 & 21 & .000 \\
\hline
\end{tabular}

Based on the output, $p$ the value for the paired t-test on the control class was .084. Since $p>\alpha, H_{0}$ is accepted. It can be concluded that significant differences were absent between student's learning achievements before and after the treatment. It demonstrates that learning achievements with a conventional mode (usually implemented) did not generate good results.

The $p$ score for the paired t-test on the experimental class was .000. Since $p<\alpha$, $H_{0}$ is rejected. It can be concluded that significant differences were present between the student's learning achievements before and after the ethnomathematics-based learning material with a fraction theme was implemented. Due to the significant difference, an 
independent t-test was carried out to discover the difference between experimental class students' learning achievements.

To clarify the test results and test the paired t-test on the post-test results of students' learning achievement, the researcher also conducted an independent t-test. If the post-test value test results give significant results, it can be concluded that the treatment is given.

Table 4

Independent Samples Test

\begin{tabular}{|c|c|c|c|c|c|c|c|c|c|c|}
\hline & & $\begin{array}{r}\text { Leve } \\
\text { Tes } \\
\text { Equal } \\
\text { Varia }\end{array}$ & $\begin{array}{l}\text { ne's } \\
\text { for } \\
\text { ity of } \\
\text { nces }\end{array}$ & & & & for Equa & $y$ of Means & & \\
\hline & & $\mathrm{F}$ & Sig. & $\mathrm{t}$ & df & $\mathrm{p}$ & MD & $\begin{array}{l}\text { Std. Error } \\
\text { Difference }\end{array}$ & $\begin{array}{r}95 \% \text { Co1 } \\
\text { Interva } \\
\text { Diffe }\end{array}$ & $\begin{array}{l}\text { fidence } \\
\text { of the } \\
\text { ence }\end{array}$ \\
\hline & & & & & & & & & Lower & Upper \\
\hline & $\begin{array}{c}\text { Equal } \\
\text { variances } \\
\text { assumed }\end{array}$ & 1.269 & .266 & -2.488 & 44 & .017 & -9.879 & 3.971 & -17.882 & -1.875 \\
\hline $\begin{array}{l}\text { Post- } \\
\text { Test }\end{array}$ & $\begin{array}{c}\text { Equal } \\
\text { variances } \\
\text { not } \\
\text { assumed }\end{array}$ & & & -2.492 & 43.892 & .017 & -9.879 & 3.964 & -17.869 & -1.889 \\
\hline
\end{tabular}

Based on the SPSS output, the Sig. Value in the Levene's Test for Equality of Variances column was .266. Since $p>\alpha$, it can be concluded that the variance of both samples was homogeneous. The t-test result was evident on the equal variances assumed row. Based on the results, the $p$ value was .017 . Since $p<.05, H_{0}$ is rejected. Hence, it can be concluded that there was a significant difference in the average posttest score for the learning achievement results of class III students of MI Roudlotul Huda Sekaran Gunungpati. Due to the significant difference in the average post-test score for the learning achievement results of class III students of MI Roudlotul Huda Sekaran Gunungpati, the application of teaching materials with an ethnomathematics approach with the fraction theme was effective on the learning achievement of class III students of MI Roudlotul Huda Sekaran Gunungpati.

The results of learning achievement before and after being given certain treatment obtained by each student in the control class and the pretest and post-test experiments are depicted in the following diagram: 


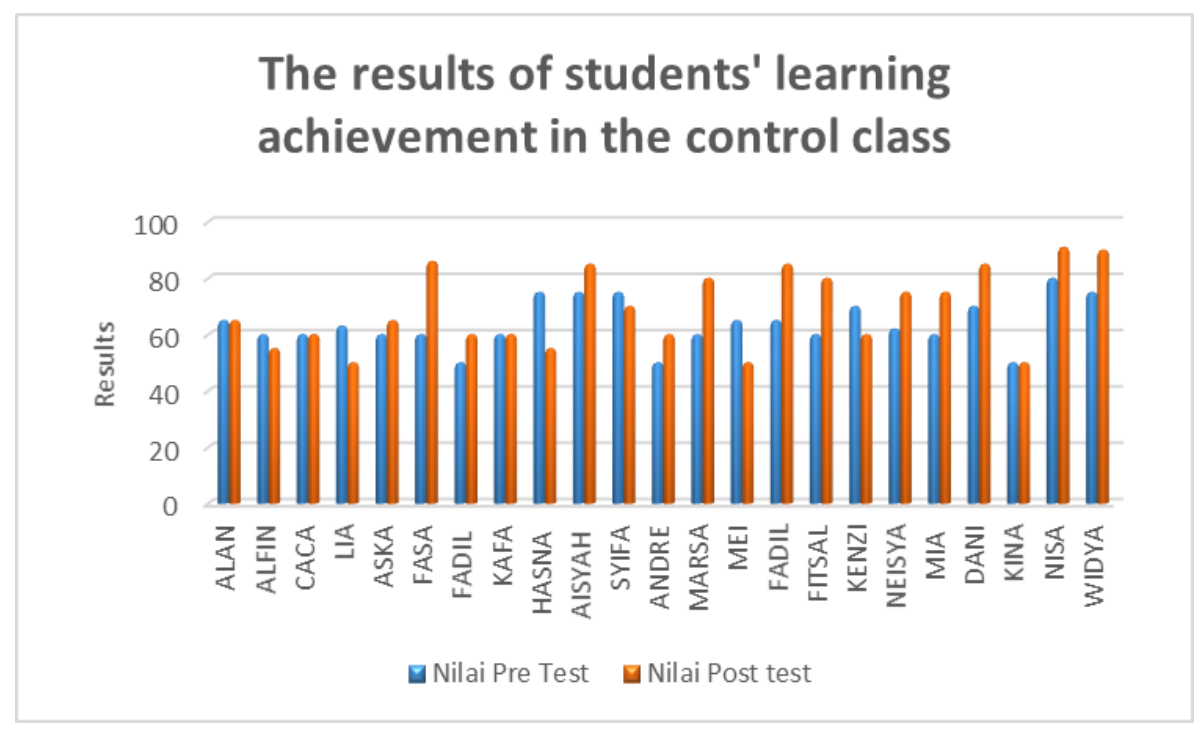

Figure 1

The Results Of Students' Learning Achievement In The Control Class

\section{The results of students' learning achievement in experiment class}

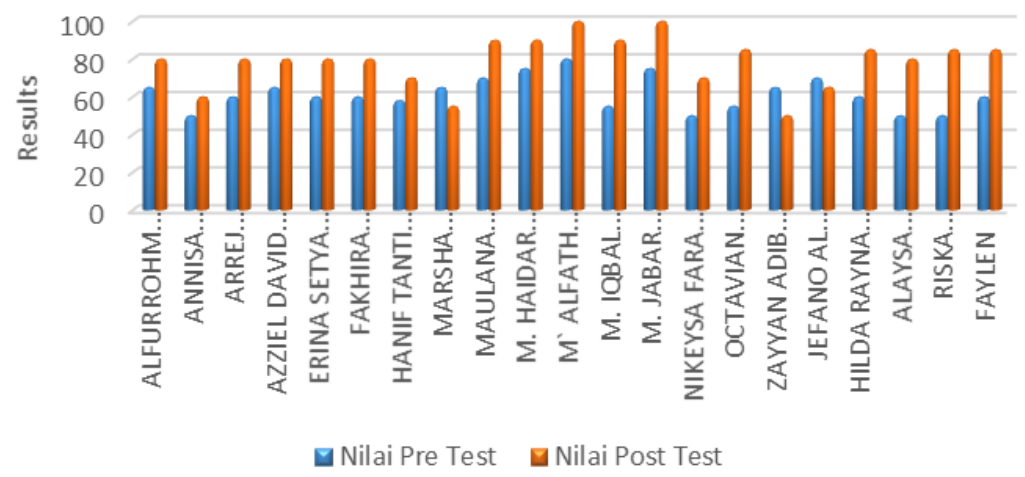

Figure 2

The Results Of Students' Learning Achievement In Experiment Class 


\section{The Improvement of Learning Outcomes in Control and Experimental Classrooms}

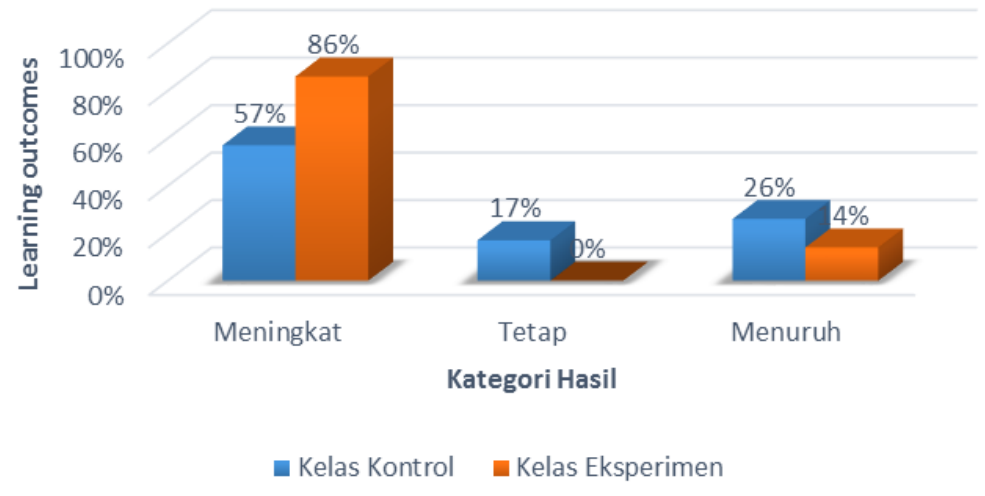

Figure 3

The Improvement of Learning Outcomes in Control and Experimental Classrooms

Based on the diagram above, it is revealed that the increase in learning achievement in the control class was 5.30, while in the experimental class was 17.24. Fifty-seven percent of students in the control class experienced an increase in learning achievement, $17 \%$ did not experience an increase or decrease, and $26 \%$ experienced decreased learning achievement results. The results of student learning achievement obtained in the experimental class increased, where $86 \%$ of students experienced an increase in interest and 14\% experienced a decrease. It shows that the application of teaching materials with an ethnomathematics approach with the theme of fractions on the learning achievement results of class III students of MI Roudlotul Huda Sekaran Gunungpati was effective. The difference in the mean increase of $29 \%$ higher than students' learning achievement in the control class using the conventional learning method.

After undergoing the validation of the expert teams, the textbook cover design with the theme of fractions with an ethnomathematics approach is as follows: 


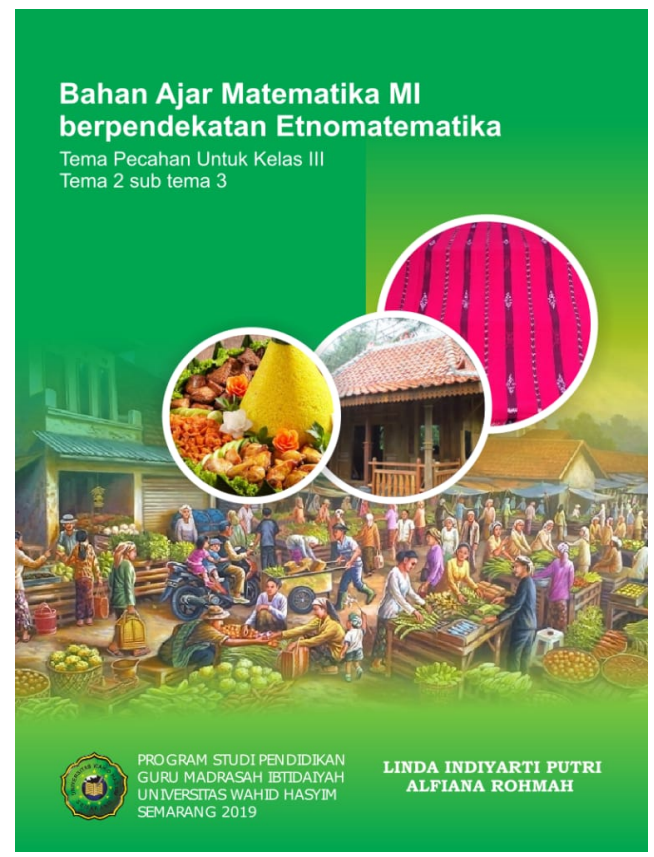

Figure 4

Cover Design Of The Ethnomathematics-Based Teaching Book

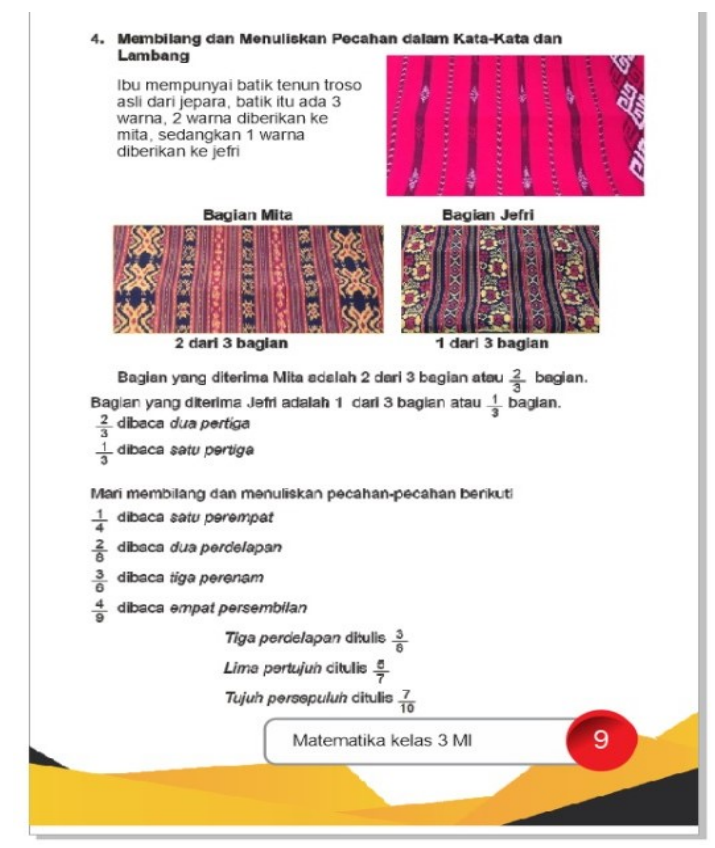

Figure 5

Material Design Of The Ethnomathematics-Based Teaching Book Presenting A Traditional Culture Product (Torso Woven Fabric)

The application of teaching materials with an ethnomatic approach that can improve student achievement in this study is in line with the findings of the research of 
Verner et.al that the ethno-mathematical approach can increase learning involvement and motivation because of the recognition of student culture. ${ }^{22}$ The findings of this study also strengthen the results of Utami et.al's research that ethno-mathematics brings mathematics learning closer to students' thinking because learning is more relevant to the surrounding cultural environment. ${ }^{23}$ This means that the increase in student learning achievement generated through the application of teaching materials in this study contributes to enriching the evidence of previous findings about the impact of the ethnomatematic approach in increasing the effectiveness of Mathematics learning.

\section{CONCLUSION}

Based on the results of research on the effectiveness of learning fraction mathematics with the ethnomathematical approach, it can be concluded that: (1) the classes which have learning fractions of the ethnomathematics approach achieved classical completeness, (2) the average of the students' learning outcomes who are subjected to the fraction of the ethnomathematics approach is higher than the average the students' learning outcomes taught by expository learning, (3) the response of students to the textbooks after being subjected to learning fractions of an ethnomathematics approach is better than the students' attitude before learning about fractions of an ethnomathematics approach.

Based on the research results, learning the fraction of the ethnomathematics approach can be used as alternative learning to improve the students' learning outcomes. The teacher is supposed to use objects in the surrounding environment, especially those related to local culture, as teaching aids so that learning becomes more contextual and it can foster love and concern of the students towards culture. It is necessary to conduct further research on learning fractions of the ethnomathematics approach as a development of this research, and the teachers are supposed to continue to conduct learning research to find the appropriate method to improve the students' mathematical communication skills.

22 Verner, Massarwe, and Bshouty, "Constructs of Engagement Emerging in an Ethnomathematically-Based Teacher Education Course."

${ }^{23}$ Niken Wahyu Utami, Suminto A. Sayuti, and Jailani Jailani, "Indigenous Artifacts from Remote Areas, Used to Design a Lesson Plan for Preservice Math Teachers Regarding Sustainable Education," Heliyon 7, no. 3 (March 1, 2021): e06417, https://doi.org/10.1016/j.heliyon.2021.e06417. 


\section{REFERENCES}

Abi, Alfonsa M. "Integrasi Etnomatematika Dalam Kurikulum Matematika Sekolah." JPMI (Jurnal Pendidikan Matematika Indonesia) 1, no. 1 (2017): 1. https://doi.org/10.26737/jpmi.v1i1.75.

Astuti, Nurmayuni. “Analisis Pengetahuan Prosedural Siswa SMA Kelas X Berdasarkan Tipe Kepribadian Dalam Menyelesaikan Soal Matematika." Ekuivalen Pendidikan Matematika 31, no. 1 (February 5, 2018). https://doi.org/10.37729/ekuivalen.v31i1.4355.

Fitriatien, Sri Rahmawati. "Pembelajaran Berbasis Etnomatematika." Surabaya: Pascasarjana Universitas Negeri Surabaya, 2016. https://www.researchgate.net/profile/Sri-

Fitriatien/publication/317318097_Pembelajaran_Berbasis_Etnomatematika/links /5931a4b2a6fdcc89e7a37493/Pembelajaran-Berbasis-Etnomatematika.pdf.

Lin, Fou-Lai, Ting-Ying Wang, and Kai-Lin Yang. "Description and Evaluation of a Large-Scale Project to Facilitate Student Engagement in Learning Mathematics." Studies in Educational Evaluation 58 (September 1, 2018): 17886. https://doi.org/10.1016/j.stueduc.2018.03.001.

Mahendra, I Wayan Eka. "Project Based Learning Bermuatan Etnomatematika Dalam Pembelajar Matematika.” JPI (Jurnal Pendidikan Indonesia) 6, no. 1 (2017): 106-14. https://doi.org/10.23887/jpi-undiksha.v6i1.9257.

Malasari, Nur, and Arif Rahman Hakim. "Pengembangan Media Belajar Pada Operasi Hitung Untuk Tingkat Sekolah Dasar." JKPM (Jurnal Kajian Pendidikan Matematika) 3, no. 1 (2017): 11. https://doi.org/10.30998/jkpm.v3i1.1911.

Minister of Religious Affairs. Al-Quran Tajwid Dan Terjemahnya Dilengkapi Dengan Asbabun Nuzul Dan Hadits Shahih. Bandung: Syaamil Quran, 2010.

Mulyatiningsih, Endang, and Apri Nuryanto. Metode Penelitian Terapan Bidang Pendidikan. Bandung: Alfabeta, 2014.

Nurhayati, Tati, Dwi Anita Alfiani, and Dewi Setiani. "The Effect of Crossword Puzzle Application on The Students' Learning Motivation in Science Learning." Al Ibtida: Jurnal Pendidikan Guru MI 6, no. 1 (2019): 124. https://doi.org/10.24235/al.ibtida.snj.v6i1.4186.

Putri, Distia. "Pengaruh Apersepsi Dan Motivasi Terhadap Hasil Belajar IPS Kelas V SD Negeri 16 Kota Bengkulu." Diploma Thesis, IAIN Bengkulu, 2019. http://repository.iainbengkulu.ac.id/3736/.

Putri, Linda Indiyarti, and Abdul Basir. "Papan Jam Analog: Media Edukatif Pembelajaran Matematika Madrasah Ibtidaiyah." Edumatika: Jurnal Riset $\begin{array}{llllll}\text { Pendidikan Matematika 3, no. } & 1 & \text { (2020): } & 33 .\end{array}$ https://doi.org/10.32939/ejrpm.v3i1.501.

Ratnaningsih, Sita, and Genasty Nastiti. "Upaya Meningkatan Motivasi Belajar Siswa Dengan Menggunakan Media Gambar Pada Pembelajaran Tematik Di Sekolah Dasar." Al Ibtida: Jurnal Pendidikan Guru MI 5, no. 2 (2018): 275. https://doi.org/10.24235/al.ibtida.snj.v5i2.3397. 
Sirate, Sitti Fatimah S. "Menggagas Integrasi Multikultur Pembelajaran Matematika: Suatu Telaah Etnomatematika." Auladuna: Jurnal Pendidikan Dasar Islam 2, no. 2 (December 31, 2015): 246-63. http://journal.uinalauddin.ac.id/index.php/auladuna/article/view/880.

Sitorus, Jonni and Masrayati. "Students' Creative Thinking Process Stages: Implementation of Realistic Mathematics Education." Thinking Skills and Creativity 22 (December 1, 2016): 111-20. https://doi.org/10.1016/j.tsc.2016.09.007.

Sugiyono. Metode Penelitian Dan Pengembangan. Bandung: Alfabeta, 2017.

Supiyati, Sri, Farida Hanum, and Jailani. "Ethnomathematics in Sasaknese Architecture." Journal on Mathematics Education 10, no. 1 (2019): 47-57. https://doi.org/10.22342/jme.10.1.5383.47-58.

Suryaningsih, Cornelia, and Detalia Noriza Munahefi. "Penerapan Puzzle Bernuansa Etnomatematika Melalui Permainan Engklek Pada Materi Bangun Datar." PRISMA, Prosiding Seminar Nasional Matematika 4 (February 24, 2021): 11118. https://journal.unnes.ac.id/sju/index.php/prisma/article/view/45008.

Utami, Niken Wahyu, Suminto A. Sayuti, and Jailani Jailani. "Indigenous Artifacts from Remote Areas, Used to Design a Lesson Plan for Preservice Math Teachers Regarding Sustainable Education." Heliyon 7, no. 3 (March 1, 2021): e06417. https://doi.org/10.1016/j.heliyon.2021.e06417.

Verner, Igor, Khayriah Massarwe, and Daoud Bshouty. "Constructs of Engagement Emerging in an Ethnomathematically-Based Teacher Education Course." The Journal of Mathematical Behavior 32, no. 3 (September 1, 2013): 494-507. https://doi.org/10.1016/j.jmathb.2013.06.002.

Verner, Igor, Khayriah Massarwe, and Daoud Bshouty. "Development of Competencies for Teaching Geometry through an Ethnomathematical Approach." The Journal of Mathematical Behavior 56 (December 1, 2019): 100708. https://doi.org/10.1016/j.jmathb.2019.05.002.

Yuningsih, Nining, Indah Nursuprianah, and Budi Manfaat. "Eksplorasi Etnomatematika Pada Rancang Bangun Rumah Adat Lengkong." Jurnal Riset Pendidikan Matematika Jakarta 3, no. 1 (February 24, 2021): 1-13. https://doi.org/10.21009/jrpmj.v3i1.19517. 
The Development of Fraction...

This page is intentionally left blank

182 | Al-Bidayah, Volume 12, Number 2, December 2020 